\begin{tabular}{cc}
$\begin{array}{c}\text { Yanbu Journal } \\
\text { of } \\
\text { Engineering } \\
\text { and Science }\end{array}$ & Vol. 7, October $2013(1434 \mathrm{H})$ \\
\hline \hline ISSN: $1658-5321$ & www.yjes.org.sa
\end{tabular}

\title{
LOCALIZATION PHENOMINA AND FRACTURE ENERGY OF CONCRETE AT EARLY AGES
}

\author{
Fawzy. M. A. El-Behairy \\ Civil Engineering Dept., Faculty of Engineering, Najran University, Saudi Arabia. \\ E_mail:Fawzyb99@yahoo.com
}

\begin{abstract}
Several experimental studies have been done long time ago to calculate the fracture energy of concrete $[2,6]$. Most of these studies neglected the loss of energy due to the frictional process in the mechanism of experimental set up. All these studies have used the indirect tensile testing method, as a suitable approach for determining the fracture energy of concrete of mature age $[3,7]$. However all these experimental studies have not investigated the crack or the localization process of young age concrete yet.

So, to study the fracture and localization process at early ages of concrete, this experimental investigation study is done. Fracture energy for concrete at early ages is estimated experimentally considering the weather of Kingdom of Saudi Arabia. The specimens at early age are tested to calculate the fracture energy of concrete using a direct tension test, taking into consideration the loss of energy due to the frictional process in the mechanism of experimental set up. Also the crack localization is considered during the experiment, as dealing with the localized fracture. In this experimental work, the measurements reach to the post peak softening branch of concrete using the direct tension. The results show that there is a fairly good agreement between the experimental results and the numerical output using the Modified Lattice Model $[9,10,11]$.
\end{abstract}

Keywords: Fracture energy, Localization, Early Age, Softening, Modified Lattice Model.

\section{INTRODUCTION}

\subsection{GENERAL}

The problem of fracture in massive concrete structures at early age during or immediately after construction is a major design concern to practicing engineers. Such fractures are primarily caused by the differential temperature gradient due to the heat generated by the process of hydration. Although there are code provisions (ACI Committee 207- 2000, ACI Committee 3182003) to cope up with such cracks $[4,5]$, the actual mechanism of such cracking and strain localization in concrete is still a matter of research. The rapid increase in the number of such large scale structures such as dams of hydroelectric power plants, basement concrete of nuclear power plants, large pavements, bridge piers etc. In the design of plain or reinforced concrete structures, cracking is taken into account in predicting the behavior in service conditions since the length, width and spacing of cracks have major influence on structural behavior as well as on its long term durability. Since in large scale structures, cracks tend to form from the very beginning of construction, it is necessary to understand the fracture characteristics of concrete at early ages. 
All the previous works have a similarity that the analysis was done in the framework of classical continuum plasticity or damage modeling and most of them neglected fracture energy or the postulates of fracture mechanics [20]. We are still lacking an adequate numerical model or method to successfully describe such a complex process.

In this research, we focus our attention on the computational mechanics of early age concrete, which is partly plastic and partly brittle frictional material. Failure of such material is characterized by highly non-linear stress-strain and volume change relations and its failure usually involves strain localization in the form of cracks or shear bands. The main objective of the present study is thus the clarification of the fracture and localization problems of concrete at early age through finite element application. In this study the Modified Lattice Model is implemented as a numerical analysis.

\section{EXPERIMENTAL INVESTIGATION OF CONCRETE FRACTURE AT EARLY AGES}

\subsection{INTRODUCTION}

In this experiment the effect of lateral loads on several RC elements are done. The loading was continuously carried out until the failure of the RC element, calculate the area under the experimental load vs. displacement curve to get the total fracture energy and then divide this quantity by the cross sectional area at the notch to get the unit fracture energy $\mathrm{G}_{\text {f }}$. One of the disadvantages of this method, is that the fracture area is relatively small compared to the overall volume which results in a somewhat overestimated value of fracture energy.

During this test, the experiment must be carried out at a slow loading rate to avoid any dynamic effect and the effect of dead load

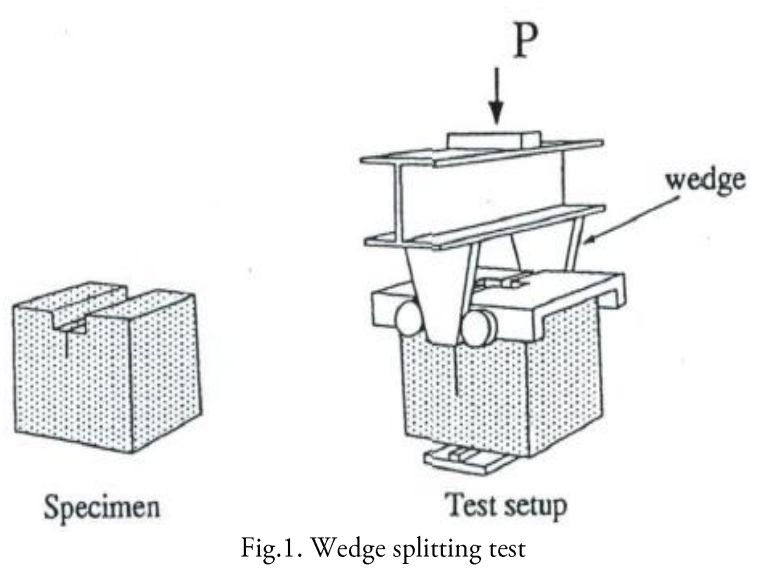

must be taken into account in the process of calculation.

This method is suitable for hardened concrete only. Because at early age, concrete is too soft to hold its own weight if any beam is made. Another method is the wedge splitting test. It was first proposed by Tschegg and Linsbauer (2006) which seems to be very effective in determination of the fracture energy as in Fig.1. The advantage of wedge splitting test over three point bending test is that its crack area is large compared to the volume of the specimen and it is suitable for high rate loading. Dead weight also has no influence on the fracture energy because in this method, fracture energy is calculated on the basis of the horizontal component of the force and the crack opening displacement.

\subsection{TEST SETUP}

This section describes the test specimens and test set up machines. Mix and casting procedures are also described. These tests are performed in the strength and concrete laboratory.

\subsubsection{Testing Machines}

A typical setup of the testing apparatus is shown in Fig.2. Using ordinary testing machines, it is quite difficult to get the post peak softening branch of concrete in direct tension test. For this reason, two different types of testing machines were used 
(Lokuliyana and Tanabe 2002) [7,13]. One for concrete at early ages and the other one for later ages of concrete. For strengths equal to or more that $0.5 \mathrm{MPa}$ or ages over $1 \mathrm{lhr}$ a high stiffness testing machine was used (Fig.2.). Due to the high stiffness loading columns, this machine was able to get the softening branch of both tension and compression with high accuracy.

The minimum loading rate that can be used in this Machine is $2.0 \times 10^{-4} \mathrm{~mm}$ and this is controlled by a computer. The maximum tensile loading capacity of this machine was $150 \mathrm{kN}$. The maximum and minimum compressive loading capacity was $1500 \mathrm{kN}$ and $1.0 \mathrm{kN}$ respectively. The other testing machine which was used to test specimens at early age (ageless that 11 hrs or strength less than $0.5 \mathrm{MPa})$ had the maximum and minimum loading capacities of $50 \mathrm{kN}$ and $0.031 \mathrm{kN}$ respectively.

For this machine, the loading rate was approximately $0.18 \mathrm{MPa}$ per minute. The strain was controlled manually during loading. The loading speed of tension testing was 0.1 $\mathrm{MPa}$ to $0.3 \mathrm{MPa}$. The time from loading to the failure varied from a few minutes to over

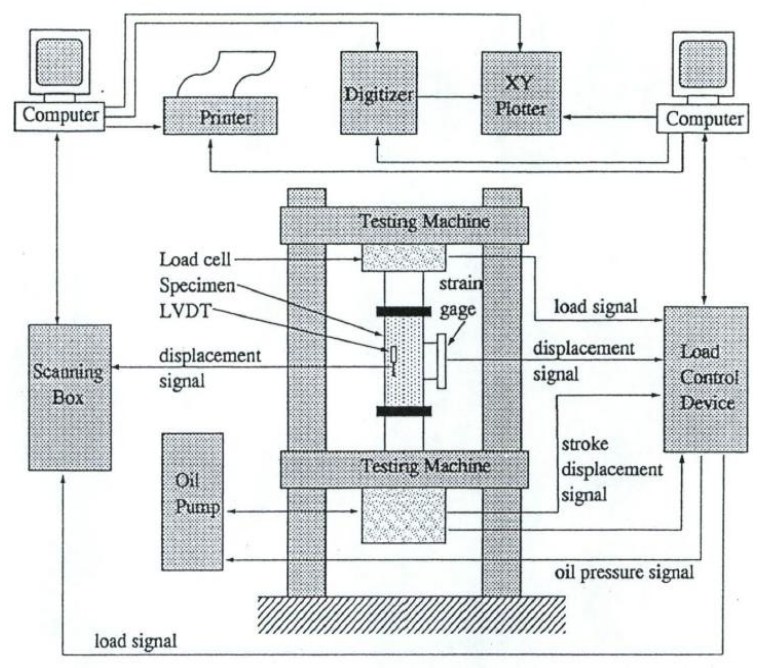

Fig. 2. Experimental setup of the high stiffness testing apparatus
10 minutes according to the strength of the specimen and loading rate.

\subsubsection{Specimens}

The size of the specimens used in the series of test was rectangular prisms having dimension of $300 \mathrm{~mm} \times 140 \mathrm{~mm} \times 40 \mathrm{~mm}$. To facilitate loading, each end of specimens had two pieces of $18 \mathrm{~mm}$ diameter steel rods embedded. The length of the rods was about $100 \mathrm{~mm}$ to ensure proper bond as shown in Fig. 2.3. The specimens were cast in steel molds having a pair of plastic plates to form notch at the middle of the specimen. On the front face of the specimen six pairs of steel studs were placed for the attachment of strain gauges. Displacement transducer type strain gages were used to measure strains across the fracture process zone. The distance between the two studs in a pair, i.e. the gage length, was taken as $20 \mathrm{~mm}, 30 \mathrm{~mm}$ and $40 \mathrm{~mm}$. Another two sets of strain gages were affixed on the two sides of the specimen with a gage length of $50 \mathrm{~mm}$ to measure vertical strain at the sides as shown in Fig.4.

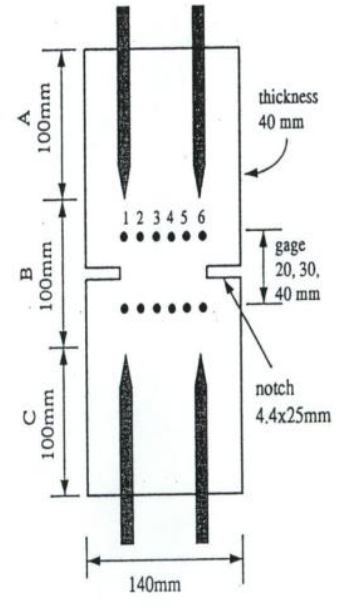

Fig.3. Direct Specimen Details

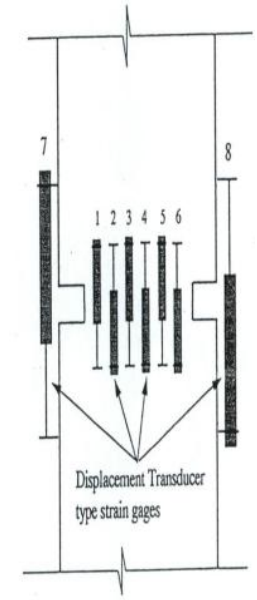

Fig.4. Details of Tension the Location of Strain Gages

\subsubsection{Concrete Mix and Casting of Specimens}

The proportion of the different constituents of the concrete mix is listed in Table 1 Coarse aggregate was crushed stone of maximum aggregate size $13 \mathrm{~mm}$. It came from the 
Yoshino river of Tokushima Prefecture. Fine aggregate was the river sand from the same river with a maximum aggregate size of $5 \mathrm{~mm}$. It had fineness modulus of 2.50. The specific gravity of the aggregate and cement was 2.60 and 3.15 respectively (Lokuliyana and Tanabe 2002).

Concrete was mixed manually and poured in to the mold and compacted by a vibrator having vibration frequency of $220 \mathrm{~Hz}$ to 250 $\mathrm{Hz}$. The vibrator was applied for one to three seconds. The mixing temperature was $30{ }^{\circ} \mathrm{C}$. Time was measured from the moment water was added to the mix. The mold was placed horizontally during casting. Specimens tested at very early ages were removed from molds just before testing. Others specimens were removed from molds after 24 hours and were placed in water bath at a temperature of $20^{\circ} \mathrm{C}$.

TABLE 1: CONCRETE MiX PROPORTIONS

\begin{tabular}{|l|l|l|l|l|l|l|}
\hline \multirow{2}{*}{$\begin{array}{l}\text { Air } \\
(\%)\end{array}$} & \multirow{2}{*}{$\begin{array}{l}\text { W/C } \\
\text { Ratio }\end{array}$} & \multicolumn{4}{|l|}{ Mix Quantities $(\mathrm{kg} / \mathrm{m})$} & \multirow{2}{|l|}{$\begin{array}{l}\text { Slump } \\
(\mathrm{cm})\end{array}$} \\
\cline { 3 - 6 } & & Water & Cement & $\begin{array}{l}\text { Fine } \\
\text { Agg. }\end{array}$ & $\begin{array}{l}\text { Coarse } \\
\text { Agg- }\end{array}$ & \\
\hline 2.5 & 0.55 & 185 & 336 & 840 & 1008 & 8 \\
\hline
\end{tabular}

\subsubsection{Preliminary Testing}

In order to get some idea on the feasibility of the testing procedure some preliminary testing with different notch configuration was made (Lokuliyana and Tanabe 1992). For this purpose specimens were tested without notch at the age of $15 \mathrm{hrs}$. Another two sets of specimens were also tested at the same age but with notches of $1.4 \mathrm{~mm}$ and $4.4 \mathrm{~mm}$ width. The notches were made by diamond saw cutting machine. For un-notched specimens, the crack formed not at the center but at a distance of approximately $90 \mathrm{~mm}$ from the end. At this location exists the ends of the embedded steel bars. So, the failure at this position can be considered due to the weaker concrete and imperfection caused by the presence of the steel bars. In the case of 1.4 mm wide notch, crack still formed at a similar place before. But for the notch of $4.4 \mathrm{~mm}$ width crack formed at the central position through the notch. In this test, electrical wire gage type strain gages were placed on the front face of the specimen and during testing most of the gages were removed by the failing concrete. This was another difficulty faced in placement of the gages in early age concrete. This difficulty was overcome by using LVDT type strain gages which were fixed to specimens using small studs as shown in Fig.4. and Fig.5.

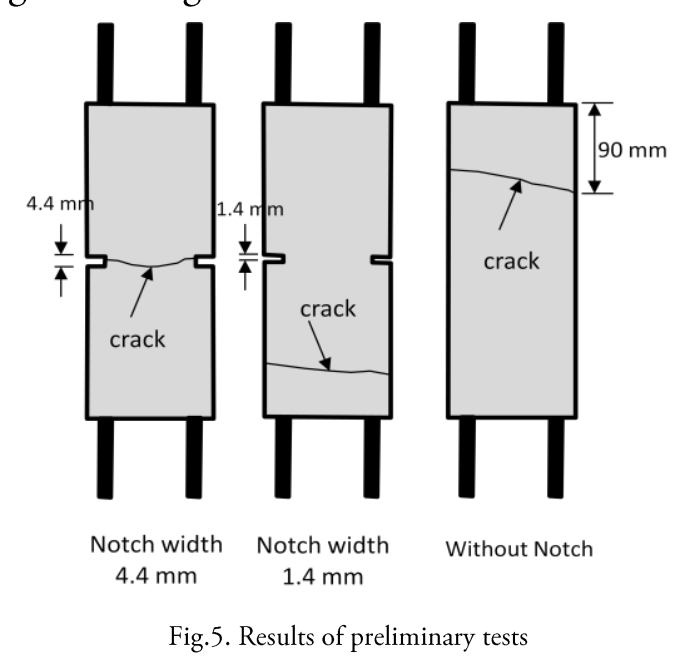

\subsubsection{Testing Specimens at Early Ages}

Tests on concrete specimens were made at different ages. Due to the difficulties in preparing and fixing the specimens in the testing machines, the time interval between ages was not regular. Tests on concrete specimens were performed at ages of $8,9,12$, $16,18,20,22,24,43,48,72,80,96,102$, 104 and 317 hrs after casting of specimens. The effect of gage length was studied by varying the gage lengths. The different gage lengths that were used were 20,30 and 40 $\mathrm{mm}$. Out of the set of the test results, the results of a test specimen tested at the age of 20 hours with gage length of $20 \mathrm{~mm}$ is selected and the variation of strain along the crack path for peak load and at failure is shown in Fig.6. 


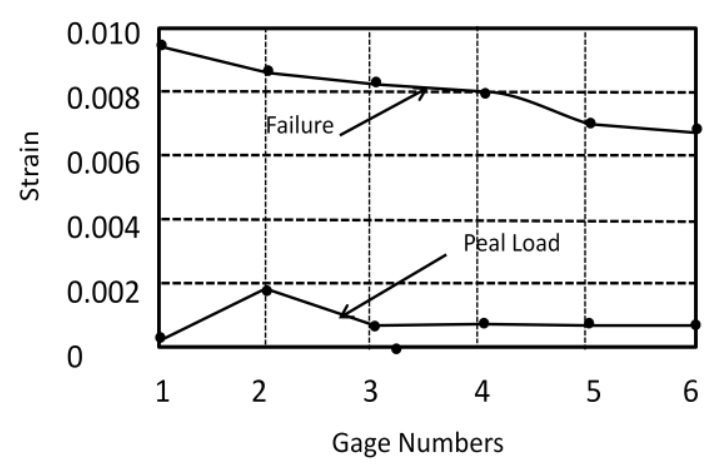

Fig.6. Strain distributions for a 20 hour specimen

\subsection{DETERMINATION OF FRACTURE ENERGY}

The area under the stress-strain diagram gives the fracture energy per unit volume of the fracturing material in the fracture process zone. However, in fracture mechanics the definition of fracture energy is defined in a different way. Fracture energy, $\mathrm{G}_{\mathrm{f}}$, is defined as the amount of energy required to produce a cracked surface of unit area. Thus if we multiply the width of the fracture process with the area of the stress-strain diagram then we obtain the fracture energy $G_{f}$ thus

$$
G_{f}=w \int_{0}^{\infty} \sigma d \varepsilon
$$

TABLE 2: SUMMARY OF EXPERIMENTAL RESULTS

\begin{tabular}{|l|l|l|l|}
\hline Age (hours) & $\begin{array}{c}\text { Young's modulus } \\
(\mathrm{MPa})\end{array}$ & $\begin{array}{c}\text { Tensile } \\
\text { strength } \\
(\mathrm{MPa})\end{array}$ & $\begin{array}{c}\text { Fracture } \\
\text { Energy } \\
\mathrm{G}_{\mathrm{f}} \\
\mathrm{N} / \mathrm{mm}\end{array}$ \\
\hline 9 & 400 & 0.14 & 8 \\
\hline 16 & 1000 & 0.25 & 24 \\
\hline 24 & 6000 & 0.80 & 28 \\
\hline 48 & 8000 & 1.00 & 36 \\
\hline 72 & 11000 & 1.50 & 54 \\
\hline 102 & 14000 & 2.20 & 84 \\
\hline
\end{tabular}

Where $\omega$ is the width of the fracture process zone, $\sigma$ is the stress normal to the crack surface and $\varepsilon$ is the strain normal to crack surface. For the experimental determination of the fracture energy, we make use of Eq. 1. We use the stress strain data obtained from experiments and consider the gage length as the width of the fracture process zone. Using the above procedure, fracture energy was calculated for different ages of concrete based on the experimentally obtained stress-strain relations. Since a total of eight strain gages were used per specimen and also there were different gage lengths, an appropriate averaging was made in determining the fracture energy. Other physical properties of concrete such as Young's modulus, tensile strength etc. was also determined from the experimental results. A summary of the experimentally obtained results are presented in Table 2.

Based on the experiments, Lokuliyana and Tanabe (2002) made a regression analysis to obtain an empirical equation relating the fracture energy with the other physical properties of concrete [16]. In doing so, they assumed a linear relationship between the characteristic length $1_{\mathrm{ch}}$ and tensile strength. Through the regression analysis they obtained the following equation of fracture energy as in Eq. 2.

$G_{f}=\left(1.0-1.07 f_{t}\right) \frac{f_{t}^{2} d a}{E}$

Where $\mathrm{f}_{\mathrm{t}}$ is the tensile strength $(\mathrm{MPa}), \mathrm{da}$ is the maximum aggregate size $(\mathrm{mm}), \mathrm{E}$ is the Young's modulus $(\mathrm{MPa})$ and $\mathrm{G}_{\mathrm{f}}$ is the fracture energy in $\mathrm{N} / \mathrm{mm}$. It should be noted that the assumption of linear variation of characteristic length with the change of tensile strength may not be a good choice.

\section{NUMERICAL ANALYSIS FOR THE TEST RESULTS}

\subsection{INTRODUCTION}

At early age, concrete undergoes rapid chemical and physical changes. Shrinkage and creep also starts taking place. In this research, we are interested only in the mechanical behavior of the early age concrete under the application of load. So we will not consider the possibility of cracking due to the shrinkage or rate dependent creep. 


\subsection{NUMERICAL FinIte ELEMENT ANALYSIS}

For the purpose of numerical analysis, the Modified Lattice Model in three dimensions which is produced before by the author $[9,10,11]$ is applied. The original specimen was $300 \mathrm{~mm}$ long with a pair of $18 \mathrm{~mm}$ diameter steel rods embedded longitudinally at each end of the specimen. The length of the embedded rods was $100 \mathrm{~mm}$. Due to the presence of these rods the outer $100 \mathrm{~mm}$ portions at both end of the specimen were rather stiff compared to the central $100 \mathrm{~mm}$ portion. This is especially true when we are dealing with young age concrete. At early age both the stiffness and the strength of concrete are very low.

TABLE 3: VALUES OF MATERIAL PARAMETERS

\begin{tabular}{|l|l|l|l|l|l|l|}
\hline \multicolumn{1}{|c|}{ Age } & \begin{tabular}{c}
\multicolumn{1}{c|}{$\begin{array}{c}16 \\
\text { hrs }\end{array}$} \\
hrs
\end{tabular} & $24 \mathrm{hrs}$ & $48 \mathrm{hrs}$ & $72 \mathrm{hrs}$ & $\begin{array}{c}102 \\
\text { hrs }\end{array}$ \\
\hline$E, \mathrm{MPa}$ & 400 & 1000 & 6000 & 8000 & 11000 & 14000 \\
\hline$V$ & 0.15 & 0.15 & 0.15 & 0.15 & 0.15 & 0.15 \\
\hline$C_{1}$ & 1.0 & 1.1 & 1.0 & 1.0 & 3.0 & 1.0 \\
\hline$C_{2}$ & 5.0 & 5.5 & 4.0 & 5.0 & 5.0 & 5.0 \\
\hline$K_{u}$ & 0.009 & 0.011 & 0.01 & 0.009 & 0.01 & 0.012 \\
\hline$f_{t}, \mathrm{MPa}$ & 0.14 & 0.25 & 0.8 & 1.0 & 1.25 & 2.2 \\
\hline $\mathrm{l}, \mathrm{mm}$ & 1.6 & 2.0 & 1.0 & 1.1 & 1.1 & 0.8 \\
\hline
\end{tabular}

So it is quite reasonable to assume that for young age concrete, the two ends having embedded rod elements will behave almost rigidly as compared to the central portion.

\subsection{RESULTS AND DISCUSSIONS}

The results of the finite element analysis are shown in from Fig.7. through Fig.8. using the Modified Lattice Model [9,10,11]. These figures show the comparative aspect of the numerically obtained stress-strain diagram with the experimental one. Actually there are six strain gages in one specimen and numerically obtained data was tried to fit with all the corresponding experimental results. But due to space limitations only one diagram is shown here for each age of concrete. It should be noted that the experimentally obtained stress strain diagrams for all the strain gages of all specimens were not completely satisfactory. Because it is very difficult to handle the concrete at early ages, in a few cases the insertion of the metal studs to fix the strain gages introduced weakness along the gage fixation line and crack occurred at that line instead of occurring across the notch. Such irregular cases were discarded and the rest of the cases where fractures occurred through or near the notched section were considered only.

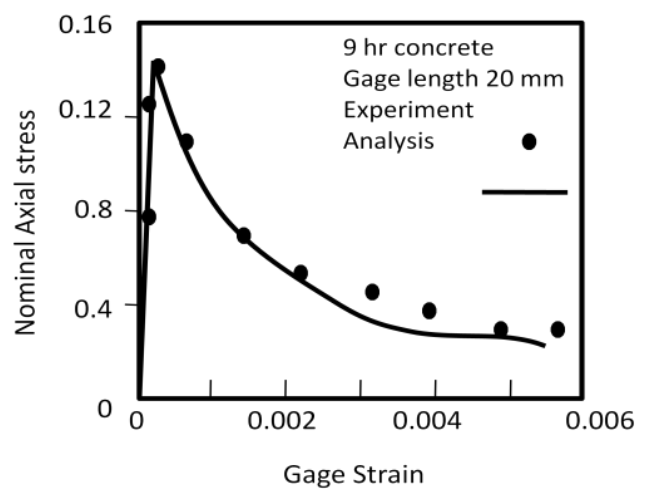

Fig. 7. stress-strain relation for 9 hrs concrete

Fig.7. to Fig.14. reveal that in all cases a fairly good agreement between experiment and numerical analysis is obtained. However, it should be noted that these results arc obtained using the data shown in Table 3 It is possible to alter the values of material parameters and to obtain different results, in that case the experimental stress-strain curves be different.

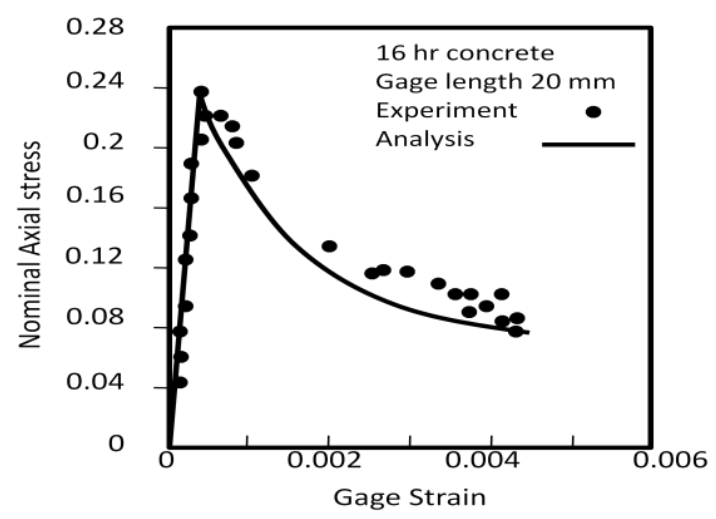

Fig. 8. stress-strain relation for 16 hrs concrete 


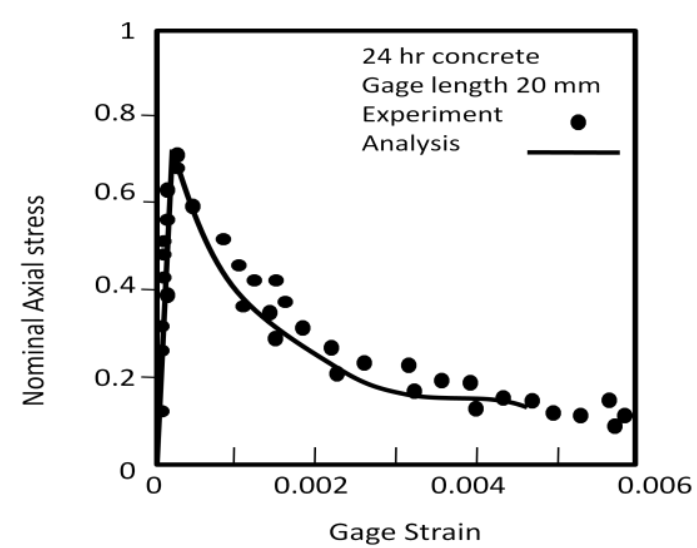

Fig. 9. stress-strain relation for $24 \mathrm{hrs}$ concrete

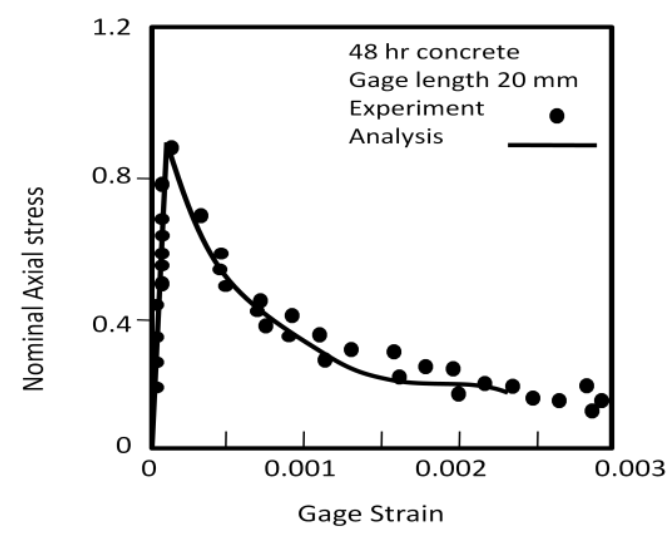

Fig. 10. stress-strain relation for $48 \mathrm{hrs}$ concrete

Also it is possible to simulate the same experimental stress strain data using different combination of material parameters $\mathrm{ku}$ and / unless we have any data related to the localization process, its width etc. In this study we are dealing with localized fracture. Therefore some pertaining data on localization and fracture must be used to fix a unique set of material parameters.

Here it is done by matching the stress strain results obtained for three different gage lengths. Although we do not have any explicit data on width of fracture process zone, the three stress-strain relations corresponding to three different gage lengths comprise a unique set and when numerical results are matched with these, we obtain a unique set of material properties. Here only the result for $72 \mathrm{hr}$ concrete is shown in detail (Fig.11., Fig.13. and Fig.14.). These figures show fairly good agreement between test and analysis for all three cases of gage length. For brevity results for only one gage length in case of other gages, a kink in the stress-strain diagram for 9 hour concrete is observed when the strain is about 0.003. Similar case happened for 102 hour concrete also. This is due to the fact that at this point all the gauss integration points (points at which stress, strains, damage etc. are monitored) reach the ultimate value of equivalent fracture strain $\mathrm{k}_{\mathrm{u}}$.

At this stage the value of softening parameter $h$ depends only on $g(K)$ and hence becomes positive at a few gauss points in the mostly stressed elements along the notch which is a violation of the gradient plasticity formulation. However, to maintain the non-local nature of the gradient plasticity approach g should not be allowed to become absolutely zero.

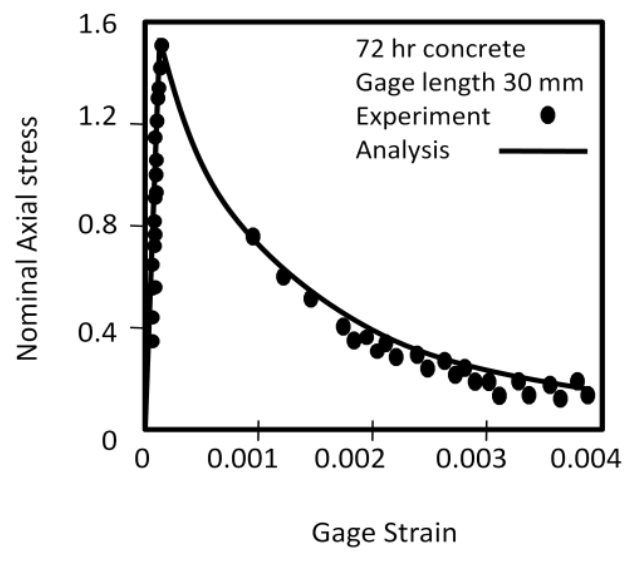

Fig. 11. stress-strain relation for 72 hrs concrete

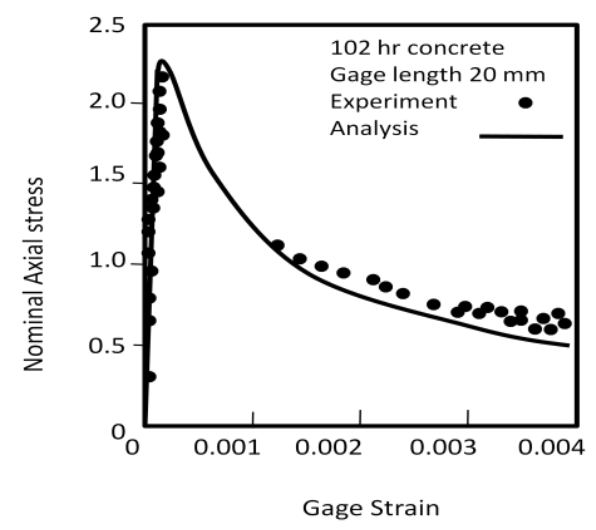

Fig. 12. stress-strain relation for 102 hrs concrete 


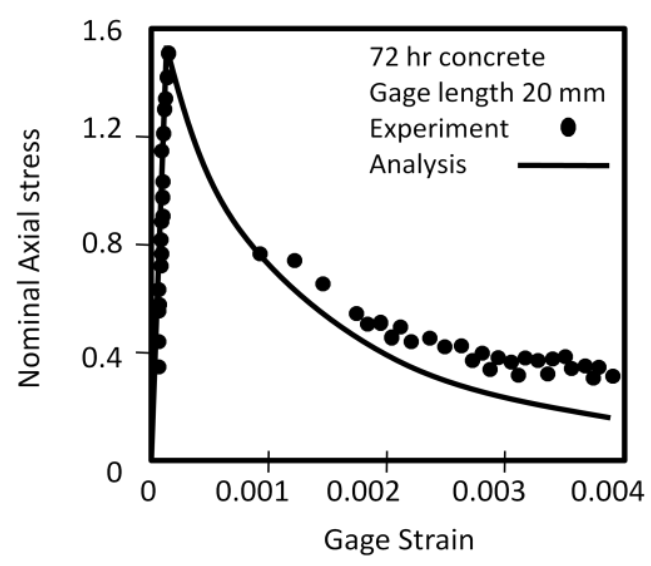

Fig. 13. stress-strain relation for $72 \mathrm{hrs}$ concrete

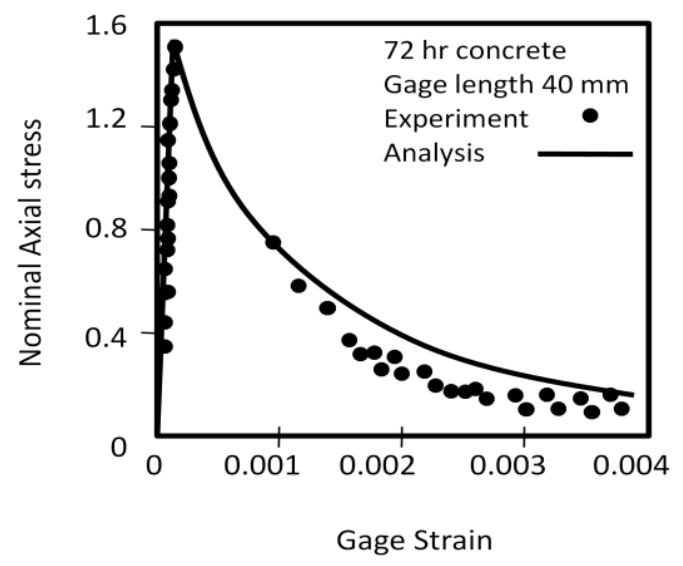

Fig. 14. stress-strain relation for 72 hrs concrete

\section{CONCLUSION}

The applicability of the gradient plasticity approach in the analysis of the fracture and strain localization phenomena of early age and reinforced concrete is investigated. The study enabled us to have a meaningful insight regarding the computational modeling of the fracture and localization of concrete especially at early age. The use of Modified Lattice Model proved to be successful in capturing strain localization phenomenon numerically.

Experimental tests are done under tension loading in servo control so that the full postpeak softening branch can be obtained experimentally. The numerical results using the Modified Lattice Model are compared with the experiment results. The main object of this study is the clarification of the fracture and localization problems of concrete at early age. The fracture energy of the early age concrete elements is calculated to capture the probability of cracking initiation. It is seen that if the fracture energy of the concrete element reaches to $0.92 \mathrm{MPa}$, the cracks start to be clear in the structural element. From the results shown in this research, it is proved that the Modified Lattice Model which is produced before by the author $[9,10,11]$ is a suitable simulation model to capture the fracture energy and the strain localization of concrete elements at early ages.

From the results, it is proved that as the concrete gets matured it becomes more brittle and the width of the fracture process zone gets narrower because the brittleness increases. The relationship of 1 with age of concrete cannot be linear because in that case 1 will become zero at some later age. This is not practical because zero / means that the width of the fracture process zone will become zero.

The results also suggest that the gradient influence factor $\mathrm{g}$ needs to be modified at the later stage of loading (when $\mathrm{k} \rightarrow \mathrm{k}_{\mathrm{u}}$ ) in order to render more realistic stress-strain relation at higher value of damage. In order to establish some definite relation of some model parameters like 1 and $k_{\mathrm{u}}$ with age of concrete or other physical properties of concrete more experimental study is necessary.

\section{ACKNOWLEDGEMENT}

The authors would like to acknowledge the head of deanship of scientific research at Najran University. This research is carried out and financially supported by Center of Scientific Research of Najran University, KSA with a serial number NU 33/11. Thanks are extended to the dean of faculty of Engineering of Najran University, for his grateful and continuous support. 


\section{REFERENCES}

[1] Anderson N. S. Ramires. J. A. "Detailing of stirrup reinforcement", ACI, Journal, pp. 507515, 1999.

[2] ACI (American Concrete Institute) Committee 446 - Fracture Mechanics: Fracture Mechanics of Concrete: Concepts, Models and Determination of material properties, December, 1989.

[3] Amanat K.M. and Tanabe T. "Investigation of Mode-Fracture of Early Age Concrete by a NonLocal Plasticity Approach”, Japan Soc. Civ. Eng. (JSCE) J. Mat. Cone. Struct. Pvmnt., (JSCE), Journal of Materials, Concrete Structures and pavements. No 2039/V-38, Pp. 185-195, August 1999.

[4] ACI (American Concrete Institute) Committee 207 "Effect of Restraint, Volume Change, and Reinforcement on Cracking of Mass Concrete", ACI Materials Journal, 87, p.271-295, 2005.

[5] ACI (American Concrete Institute) Committee 318 - Building Code Requirement for Reinforced Concrete (ACI 318-83), American Concrete Institute, Detroit, p.l 18-130, 2003.

[6] Amanat K.M. and Tanabe T. "Applicability of One Dimensional Gradient Plasticity in Identifying Fracture Process of Concrete", Japan Cone. Inst. (JCI), Vol. 17, p.1341-1346, 1995.

[7] Amanat K.M. and Tanabe T., "Crack Spacing Analysis of Reinforced Concrete by Gradient Plasticity Model, Proc. of Japan Cone. Inst. (JCI) journal, 19, Jan. 1999.

[8] Choi, I.K, and Niwa, J. "Analytical study on shear behavior of concrete beams by lattice model" JCI journal, Vol. 16, (in Japanese.), 1994.

[9] El_Behairy, F.M., Niwa, J. and Tanabe, T. A "Analytical Study on pure Tension Behavior of. Concrete columns using 3D-Lattice Model" JCI journal. Vol. 18. No.2. Pp. 263-268, 1996.

[10] El_Behairy, F.M., and Tanabe, T. A. "A study on Fundamental Characteristics of Lattice Model for reinforced Concrete Beam Analysis" Japan Sec Civ. Eng. (JSCE), Journal of Materials, Concrete Structures and pavements. No 599/V-40, Pp. 165-175, August 1998.

[11] El_Behairy, F.M., and Tanabe, T. A."Anew technique for reinforced concrete beams analysis using the modified lattice model" Journal of JCI. Vol. 19. No.2.. Pp. 477-482, 1997.
[12] JSCE, C. L. SP. 1, "Standard Specification for Design Construction of Concrete Structures" First Edition Part 1 (Design), pp. 65-69, 1996.

[13] Niwa, J. and Tanabe, T. A "Analytical Study for Shear Resisting Mechanism Using Lattice Model", Journal of JCI International workshop on Shear Concrete Structures, Pp. 130-145, 20, June 1994.

[14] Niwa, J., Yamada, K. Yokozawa, K. and Okamura, H., "Re-Evaluation of the Equation for Shear Strength of Reinforced Concrete Beams without web reinforcement", Journal Of JSCE, No. 372/V-5, Pp. 167-176, (In Japanese), 1986.

[15] Oden, J. T., and Rippereger, E. A., "Mechanism of Elastic Structure, Second 'Edition" Library of Congress Cataloging in Publication Data, ISBN 0-07-0475507-5, 1980.

[16] Thomas T. C. Hsu and Mo, Y. L. "Softening of Concrete in Torsional Members Design recommendation", ACI Journal, Vol. 88, No. 6 Pp. 674-683, July-August 1985.

[17] Vecchio, F. J. and Collins, M. P., "The Modified Compression Field Theory for Reinforced Concrete elements Subjected to Shear", ACI Journal, Pp.219-231, 1985.

[18] Vecchio, F. J. and Collins, M. P., "Stress -Strain Characteristic of Reinforced Concrete in Pure Shear", Final Report IABSE Colloquium on advanced mechanism of Reinforced Concrete, International association for Bridge and Structural Engineering, Zurich, Pp. 211-225, 1981.

[19] Architecture Institute of Japan, "Design Guidelines for Earthquake resistance Reinforced concrete building based on ultimate stress concept" Tokyo, Japan, (In Japanese), 1990.

[20] BaZant Z.P. "Mechanics of Fracture and Progressive Cracking in Concrete Structures, Chap. 1, Fracture Mechanics of Concrete: Structural Application and Numerical Calculation, Eds Sih G.C. and Di Tommaso A., Martinus Nijhoff Publishers, 1985.

[21] Edward G. NAWY "Reinforced Concrete-A Fundamental Approach", Second Edition, ISBN 0-13-771767-9, 1990.

[22] Mazars J., and Z. P. Bazant, "Cracking and Damage Strain Localization and size effect", Elsevier Applied Science, ISBN I-85166-347-9, 1999. 
ظاهرة تركيز الانفعالات وحساب طاقة الانهيار للخرسانة الدايثة الصب

\author{
فوزي محمد أحمد البحيري \\ قسم الهندسة الددنية ـ كلية الهندسة- جامعة نجر ان- المملكة العربية السعودية
}

الملخص:

في هذا البحث تم إجراء العديد من التجارب المعلية على الخرسانة حديثة الصب وفي أجو اء المملكة العربية السعودية والمتميزة بالحر ارة العالية نسبيا، وذلك مع الأخذ في الاعتبار الطاقة المفقودة نتيجة الاحتكاك للعينات أثناء عملية الصب، تم اختبار العينات الخرسانية الحديثة الصب تحت نأثير الثد المباثر وبطريقة مناسبة لحساب الطاقة اللازمة لانهيار العينة وذلك باختلاف زمن الصب. في هذا البحث تم أيضا التعرف على أماكن تركيز الانفعالات للعينات الخرسانبة الحديثة الصب تحت تأثير الثد المباشر كما نم الوصول بالعينات لما بعد القيم العظمي للإجهاد، تم مقارنة النتائج المعلية مع النتائج النظرية والمستتنجة بطريقة النموذج الضلعي المعدل Modified Lattice Model النتائج المعملية و النتائج النظرية. 